\title{
Pemberian Ekstrak Rebusan Daun Sirih Sebagai Pengganti Perak Nitrat Dalam Larutan Pengawet Bunga Potong Dendrobium 'Sonia'
}

\author{
Adduction of Betel Leaves Boiled Extract to Substitute Silver Nitrate for Preservative Solution in \\ Dendrobium 'Sonia' Cut Flower
}

\author{
Yane Riana Putri dan Dewi Sukma*
}

Departemen Agronomi dan Hortikultura, Fakultas Pertanian, Institut Pertanian Bogor (Bogor Agricultural University), Jl. Meranti, Kampus IPB Darmaga, Bogor 16680, Indonesia Telp. \& Faks.62-251-8629353 e-mail agrohort@apps.ipb.ac.id

*Penulis Korespondensi : dsukma70@yahoo.com

Disetujui : 15 Maret 2018 / Published Online 2 Januari 2019

\begin{abstract}
This experiment was conducted from April to June 2014 in the Post Harvest Laboratory and Post Graduate Room IPB, Dramaga, Bogor. The purpose of this study was to obtain the exact composition of betel leaves boiled extract as a substitution for anti-microbial silver nitrate in preservative solution to prolong the freshness of Dendrobium 'Sonia' cut flower. The treatments laid out in completely randomized design (CRD) with single factor of preservative solution. Five floral preservative solutions, distilled water as a control, silver nitrate and betel leaves boiled extract $250 \mathrm{gl}^{-1}, 350 \mathrm{gl}^{-1}$ and $450 \mathrm{gl}^{-1}$ were used. Each treatment was replicated 4 times and 5 cut flower stems were used for each replication.

The results showed that there was no significant effect of preservative solution on vase life of Dendrobium 'Sonia'. Flower freshness in all treatments were around 20 days with fresh flower left. The highest volume of preservative solution absorbed was aquades $(7.6 \mathrm{ml})$. There was positive effect to minimizing the growth of microorganism with betel leaves boiled extract as preservative solution used.
\end{abstract}

Keywords: betel leaf, dendrobium cut flower, preservative solutions, vase life

\begin{abstract}
ABSTRAK
Percobaan dilaksanakan pada April sampai Juni 2014 di Laboratorium Pasca Panen dan Ruang Forum Pasca Sarjana IPB, Dramaga, Bogor. Tujuan penelitian ini untuk mendapatkan komposisi ekstrak rebusan daun sirih yang tepat sebagai anti mikroba pengganti perak nitrat dalam larutan pengawet anggrek potong Dendrobium 'Sonia'. Rancangan yang digunakan adalah rancangan acak lengkap (RAL) dengan faktor tunggal komposisi larutan pengawet. Terdapat 5 perlakuan yaitu akuades sebagai kontrol larutan pengawet, perak nitrat dan ekstrak rebusan daun sirih $250 \mathrm{~g}^{-1}, 350 \mathrm{~g}^{-1}$ dan $450 \mathrm{~g}^{-1}$ yang diulang sebanyak 4 ulangan dengan 5 sampel tangkai bunga per ulangan.

Hasil penelitian menunjukkan bahwa penggunaan berbagai komposisi larutan pengawet tidak berpengaruh nyata dalam memperpanjang umur kesegaran anggrek potong. Kesegaran bunga anggrek Dendrobium 'Sonia' dengan penggunaan semua perlakuan larutan pengawet dapat bertahan rata-rata hingga 20 hari. Volume larutan pengawet yang diserap paling besar yaitu penggunaan akuades $(7.6 \mathrm{ml})$. Penggunaan ekstrak rebusan daun sirih konsentrasi $250 \mathrm{~g} \mathrm{l}^{-1}, 350 \mathrm{~g} \mathrm{l}^{-1}$ dan $450 \mathrm{~g} \mathrm{l}^{-1}$ dengan hasil jumlah bunga terserang cendawan yaitu 2.8, 2.3 dan 2.3 kuntum, hampir separuh jumlahnya dari penggunaan perak nitrat yaitu 5.3 kuntum, menunjukkan adanya kecenderungan positif terhadap penekanan cendawan.
\end{abstract}

Kata kunci: anggrek potong dendrobium, daun sirih, larutan pengawet, vase life 


\section{PENDAHULUAN}

Penggunaan perak nitrat $\left(\mathrm{AgNO}_{3}\right)$ sebagai salah satu bahan dalam larutan pengawet bunga potong sangat penting sebagai germisida. Hal yang disayangkan, perak nitrat mempunyai banyak kekurangan antara lain tidak dijual bebas dipasaran karena sifatnya yang toksik dan korosif, harganya cukup mahal, bersifat racun, bahan yang mudah terbakar, dapat menyebabkan iritasi pada mata, dapat merusak selaput lendir, dapat menyebabkan noda perak hitam pada kulit dan berbahaya bagi lingkungan (IPCS 2012). Oleh karena itu diperlukan bahan alternatif pengganti perak nitrat yang mempunyai harga relatif terjangkau dan dapat dibuat sendiri oleh masyarakat, yaitu ekstrak rebusan daun sirih. Daun sirih adalah bahan alami, harganya, murah dan mudah didapatkan. Sari (2006) dan Parwata (2009) mengatakan bahwa ekstrak daun sirih teruji efektif sebagai antiseptik alami. Kurniawan (2008) menggunakan larutan pengawet yang terdiri dari campuran ekstrak daun sirih $250 \mathrm{~g} \mathrm{l}^{-1}$, asam sitrat $0.15 \mathrm{~g}^{-1}$ dan gula $100 \mathrm{~g} \mathrm{l}^{-1}$ pada bunga anggrek potong Dendrobium 'Sonia' yang kesegarannya bertahan selama 22 hari. Penelitian ini bertujuan untuk mendapatkan konsentrasi ekstrak rebusan daun sirih yang tepat sebagai anti mikroba pengganti perak nitrat untuk memperpanjang masa kesegaran bunga anggrek potong Dendrobium 'Sonia'.

\section{BAHAN DAN METODE}

Bahan-bahan yang digunakan dalam penelitian ini adalah bunga potong anggrek Dendrobium 'Sonia' yang dipanen langsung dari petani anggrek di daerah Parung, Bogor, Jawa Barat. Bahan lain yang digunakan adalah akuades, daun sirih, gula, asam sitrat, $\mathrm{AgNO}_{3}$, dan air hangat. Alat-alat yang digunakan yaitu tabung bunga potong, penggaris, panci, gunting stek, botol, corong, gelas piala $1000 \mathrm{ml}$, gelas ukur 100 $\mathrm{ml}, \mathrm{pH}$ meter HM-20P, termometer, dan timbangan digital.

Bunga anggrek sebanyak 100 tangkai yang telah diperoleh dari petani anggrek di daerah Parung, Jawa Barat, dicelupkan tangkainya ke dalam air untuk menghilangkan panas lapang. Selanjutnya, bunga dikelompokkan 10 batang dan dibungkus dengan kertas agar tidak rusak karena pergesekan saat pengangkutan. Dasar tangkai bunga dibungkus plastik berisi air lalu diangkut ke laboratorium. Di laboratorium ujung tangkai bunga dipotong miring sepanjang $1 \mathrm{~cm}$ sampai 2 $\mathrm{cm}$ dalam air hangat untuk mencegah embolism dan dikelompokkan sesuai perlakuan.
Daun sirih segar yang telah dicuci ditimbang sesuai perlakuan yaitu 250 g, 350 g, $450 \mathrm{~g}$. Setelah itu masing-masing direbus dalam 1 liter air selama 10 menit setelah air mulai mendidih. Hasil rebusan dibiarkan sampai hangat dan disaring lalu ditambah gula untuk tiap perlakuan sebanyak $100 \mathrm{~g}$ dan asam sitrat sebanyak $0.15 \mathrm{~g}$. Larutan pengawet $\mathrm{P} 1$ yaitu perak nitrat $\left(\mathrm{AgNO}_{3}\right)$ sebanyak $0.5 \mathrm{~g}$ ditambah gula untuk tiap perlakuan sebanyak $100 \mathrm{~g}$ dan asam sitrat sebanyak $0.15 \mathrm{~g}$. Akuades juga dipersiapkan sebagai kontrol (P0). Tiap bahan dicampur sesuai perlakuan masing-masing dalam labu takar.

Dalam keadaan masih hangat, tiap larutan dimasukkan kedalam tabung bunga potong sebanyak $5 \mathrm{ml}$. Tiap tangkai anggrek yang telah dipotong miring ujung batangnya dimasukkan ke dalam tabung bunga potong. Jumlah tangkai anggrek untuk tiap perlakuan sebanyak 20 tangkai. Setelah perlakuan, tangkai anggrek yang telah disimpan dalam tabung bunga potong dimasukkan kedalam botol kaca agar dapat berdiri tegak dan disimpan dalam ruangan bersuhu $24^{\circ} \mathrm{C}$ $25^{\circ} \mathrm{C}$. Percobaan ini disusun menggunakan rancangan acak lengkap (RAL) dengan faktor tunggal yaitu komposisi larutan pengawet. Terdapat 5 perlakuan yang diulang sebanyak 4 ulangan dengan 5 tangkai bunga per ulangan. Pengolahan data dilakukan dengan uji $\mathrm{F}$ pada sistem SAS (statistical analysis system). Setelah diuji $\mathrm{F}$, perlakuan yang berpengaruh nyata diuji lanjut dengan DMRT (duncan multiple range test) pada taraf $5 \%$.

\section{HASIL DAN PEMBAHASAN}

\section{Kondisi Awal Penelitian}

Pada awal penelitian rata-rata jumlah kuntum total bunga sekitar 9.4 kuntum. Jumlah antara kuntum mekar dan kuntum kuncup pun berimbang untuk setiap perlakuan, yaitu rata-rata jumlah kuntum mekar 7.75 (82.64\%) sedangkan rata-rata jumlah kuntum yang masih kuncup adalah 1.63 (17.18\%). Kondisi bunga jika dilihat secara visual masih terlihat segar dan aroma segar bunga pun masih tercium. Rata-rata dan persentase jumlah kuntum total, jumlah kuntum mekar dan kuntum kuncup tertera pada Tabel 1.

Suhu ruangan selama penelitian sebesar 24 ${ }^{\circ} \mathrm{C}$ hingga $25{ }^{\circ} \mathrm{C}$. Menurut Nurcahyawati (2010) kondisi suhu ini baik untuk vase life bunga potong, karena kisaran suhu tersebut dapat memperlambat proses transpirasi, sehingga proses kemunduran bunga menjadi lambat dan bunga tidak cepat layu. 
Tabel 1. Jumlah rata-rata dan persentase kuntum total, jumlah kuntum mekar total, dan jumlah kuntum kuncup anggrek Dendrobium 'Sonia' pada awal pengamatan 0 HSP (hari setelah perlakuan)

\begin{tabular}{lrcc}
\hline Perlakuan & Kuntum Total & Kuntum Mekar & Kuntum Kuncup \\
\hline P0 & $10.6(100 \%)$ & $8.7(82.5 \%)$ & $1.9(17.8 \%)$ \\
P1 & $9.0(100 \%)$ & $7.4(82.2 \%)$ & $1.6(17.3 \%)$ \\
P2 & $9.3(100 \%)$ & $7.7(82.7 \%)$ & $1.6(17.5 \%)$ \\
P3 & $10.0(100 \%)$ & $8.3(82.5 \%)$ & $1.8(16.7 \%)$ \\
P4 & $8.1(100 \%)$ & $6.8(83.3 \%)$ & $1.4(16.7 \%)$ \\
\hline
\end{tabular}

Keterangan: P0: kontrol dengan akuades, P1: Larutan pengawet perak nitrat $0.5 \mathrm{~g}^{-1}, \mathrm{P} 2$ : Larutan pengawet daun sirih $250 \mathrm{~g} \mathrm{l}^{-1}, \mathrm{P} 3$ : Larutan pengawet daun sirih $350 \mathrm{~g} \mathrm{l}^{-1}, \mathrm{P} 4$ : Larutan pengawet daun sirih $450 \mathrm{~g} \mathrm{l}^{-1}$

Tabel 2. Jumlah rata-rata dan persentase kuntum bunga mekar anggrek Dendrobium 'Sonia' pada 2-26 HSP (hari setelah perlakuan)

\begin{tabular}{lccccc}
\hline \multirow{2}{*}{ HSP } & \multicolumn{5}{c}{ Perlakuan } \\
\cline { 2 - 6 } & P0 & P1 & P2 & P3 & P4 \\
\hline 2 & $8.8(83.8 \%)$ & $7.5(82.3 \%)$ & $7.5(83.0 \%)$ & $8.3(82.8 \%)$ & $6.8(83.3 \%)$ \\
4 & $8.8(83.8 \%)$ & $7.5(82.3 \%)$ & $7.5(83.0 \%)$ & $8.3(82.8 \%)$ & $6.8(83.3 \%)$ \\
6 & $8.8(83.8 \%)$ & $7.5(82.3 \%)$ & $7.8(85.0 \%)$ & $8.8(85.3 \%)$ & $7.0(86.0 \%)$ \\
8 & $8.8(83.8 \%)$ & $7.9(89.5 \%)$ & $8.5(91.5 \%)$ & $9.3(92.8 \%)$ & $7.3(92.5 \%)$ \\
10 & $9.3(88.3 \%)$ & $8.0(90.3 \%)$ & $8.5(91.5 \%)$ & $9.3(92.8 \%)$ & $7.3(92.5 \%)$ \\
12 & $9.3(88.3 \%)$ & $8.0(90.3 \%)$ & $8.5(91.5 \%)$ & $9.3(92.8 \%)$ & $7.3(92.5 \%)$ \\
14 & $9.3(88.3 \%)$ & $8.0(90.3 \%)$ & $8.5(91.5 \%)$ & $9.3(92.8 \%)$ & $7.3(92.5 \%)$ \\
16 & $9.3(88.3 \%)$ & $8.0(90.3 \%)$ & $8.5(91.5 \%)$ & $9.3(92.8 \%)$ & $7.3(92.5 \%)$ \\
18 & $9.3(88.3 \%)$ & $8.0(90.3 \%)$ & $8.5(91.5 \%)$ & $9.3(92.8 \%)$ & $7.3(92.5 \%)$ \\
20 & $9.3(88.3 \%)$ & $8.0(90.3 \%)$ & $8.5(91.5 \%)$ & $9.3(92.8 \%)$ & $7.3(92.5 \%)$ \\
22 & $9.3(88.3 \%)$ & $8.0(90.3 \%)$ & $8.5(91.5 \%)$ & $9.3(92.8 \%)$ & $7.3(92.5 \%)$ \\
24 & $9.3(88.3 \%)$ & $8.0(90.3 \%)$ & $8.5(91.5 \%)$ & $9.3(92.8 \%)$ & $7.3(92.5 \%)$ \\
\hline
\end{tabular}

Keterangan: P0: kontrol dengan akuades, P1: Larutan pengawet perak nitrat $0.5 \mathrm{~g}^{-1}$, P2: Larutan pengawet daun sirih $250 \mathrm{~g} \mathrm{l}^{-1}, \mathrm{P} 3$ : Larutan pengawet daun sirih $350 \mathrm{~g} \mathrm{l}^{-1}, \mathrm{P} 4$ : Larutan pengawet daun sirih $450 \mathrm{~g} \mathrm{l}^{-1}$

\section{Jumlah dan Persentase Kuntum Bunga Mekar}

Hasil sidik ragam menunjukkan bahwa pemberian larutan pengawet yang berbeda memberikan hasil yang tidak berbeda nyata terhadap jumlah kuntum bunga mekar seperti terlihat pada Tabel 2. Rata-rata jumlah kuntum bunga mekar dengan perlakuan P2, P3 dan P4 mengalami peningkatan pada $8 \mathrm{HSP}$. Hal ini dapat dikatakan bahwa bunga mengalami tingkat kemekaran optimal pada 8 HSP dengan penggunaan ekstrak rebusan daun sirih. Penggunaan perak nitrat menunjukkan tingkat kemekaran optimal pada 10 HSP sebesar 90.3\% dan penggunaan akuades sebesar $88.3 \%$.

Tingkat kemekaran pada perlakuan akuades paling kecil sesuai dengan pernyataan Sunarmani et al. tahun 1998 bahwa tidak ada tambahan makanan dari luar seperti sukrosa sebagai sumber karbohidrat dan energi untuk respirasi dan pemekaran dengan penggunaan akuades, akibatnya pemekaran lama dan sangat sedikit persentase pemekarannya. Hasil rata-rata pemekaran bunga tidak mencapai 100\% disebabkan ada beberapa kuncup bunga yang layu dan gugur sebelum mekar.

\section{Jumlah dan Persentase Kuntum Bunga Layu}

Layu pada bunga ditandai dengan mengkerutnya jaringan akibat perubahan sifat elastis karena menurunnya turgor yang dipengaruhi oleh ketersediaan air dalam sel. Kelayuan merupakan salah satu tahapan pertumbuhan pada komoditas hortikultura sebelum pembusukan atau kematian (senesence). Kejadian ini diawali dengan mulai layunya pinggiran atau tepi mahkota bunga namun kelopak masih tetap segar, kemudian diikuti dengan layunya tepi kelopak bunga (Katsum 2001). Bunga anggrek Dendrobium 'Sonia' dapat dikatakan benar-benar layu jika kelopak dan mahkota bunga telah terkulai dan menguncup. Berdasarkan uji keragaman diperoleh bahwa jumlah kuntum bunga layu untuk semua perlakuan dapat dilihat pada Tabel 3.

Hasil pengamatan jumlah kuntum layu, seperti terlihat pada Tabel 3, menunjukkan bahwa perlakuan larutan pengawet tidak mempunyai pengaruh yang berbeda secara signifikan. Kuntum P0, P1, P2 dan P3 sudah banyak mengalami kelayuan pada 6 HSP sementara pada perlakuan P4 mulai layu pada 8 HSP. Rata-rata jumlah dan 
Tabel 3. Jumlah rata-rata dan persentase kuntum bunga layu anggrek Dendrobium 'Sonia' pada 2-24 HSP (hari setelah perlakuan)

\begin{tabular}{lccccc}
\hline \multirow{2}{*}{ HSP } & \multicolumn{5}{c}{ Perlakuan } \\
\cline { 2 - 6 } & P0 & P1 & P2 & P3 & P4 \\
\hline 2 & $0.0(0.0 \%)$ & $0.0(0.0 \%)$ & $0.0(0.0 \%)$ & $0.0(0.0 \%)$ & $0.0(0.0 \%)$ \\
4 & $0.0(0.0 \%)$ & $0.0(0.0 \%)$ & $0.0(0.0 \%)$ & $0.0(0.0 \%)$ & $0.0(0.0 \%)$ \\
6 & $0.8(5.5 \%)$ & $1.0(10.3 \%)$ & $0.5(6.0 \%)$ & $0.5(5.0 \%)$ & $0.0(0.0 \%)$ \\
8 & $1.5(13.0 \%)$ & $2.3(23.0 \%)$ & $1.3(13.8 \%)$ & $1.5(13.8 \%)$ & $1.3(16.3 \%)$ \\
10 & $1.8(16.3 \%)$ & $2.8(31.3 \%)$ & $1.8(21.5 \%)$ & $2.0(20.0 \%)$ & $2.0(24.8 \%)$ \\
12 & $2.8(28.3 \%)$ & $3.8(40.0 \%)$ & $2.3(24.0 \%)$ & $2.8(29.0 \%)$ & $2.5(30.0 \%)$ \\
14 & $3.5(34.5 \%)$ & $4.8(51.3 \%)$ & $3.0(29.5 \%)$ & $3.5(34.5 \%)$ & $3.3(38.3 \%)$ \\
16 & $3.8(36.8 \%)$ & $5.3(56.8 \%)$ & $3.3(37.0 \%)$ & $4.0(39.8 \%)$ & $3.5(43.3 \%)$ \\
18 & $4.3(40.3 \%)$ & $5.8(62.5 \%)$ & $4.3(46.5 \%)$ & $4.5(47.5 \%)$ & $4.0(51.8 \%)$ \\
20 & $5.0(49.5 \%)$ & $6.8(74.8 \%)$ & $5.3(58.0 \%)$ & $6.0(56.8 \%)$ & $4.5(58.0 \%)$ \\
22 & $5.3(51.0 \%)$ & $7.8(87.0 \%)$ & $5.5(63.5 \%)$ & $6.0(58.0 \%)$ & $5.0(63.5 \%)$ \\
24 & $6.0(56.3 \%)$ & $7.8(87.0 \%)$ & $6.5(70.3 \%)$ & $6.0(64.3 \%)$ & $5.5(68.8 \%)$ \\
\hline
\end{tabular}

Keterangan: P0: kontrol dengan akuades, P1: Larutan pengawet perak nitrat $0.5 \mathrm{~g} \mathrm{l}^{-1}$, P2: Larutan pengawet daun sirih $250 \mathrm{~g} \mathrm{l}^{-1}, \mathrm{P} 3$ : Larutan pengawet daun sirih $350 \mathrm{~g} \mathrm{l}^{-1}, \mathrm{P} 4$ : Larutan pengawet daun sirih $450 \mathrm{~g}^{-1}$

persentase kuntum bunga layu terus meningkat sampai akhir pengamatan. Persentase kuntum layu dengan larutan pengawet perak nitrat mencapai $50 \%$ setelah $12 \mathrm{HSP}$, dengan perlakuan akuades mulai $20 \mathrm{HSP}$, dengan perlakuan ekstrak rebusan daun sirih $250 \mathrm{~g} \mathrm{l}^{-1}$ dan $350 \mathrm{~g} \mathrm{l}^{-1}$ serta $450 \mathrm{~g} \mathrm{l}^{-1}$ mulai 18 HSP.

\section{Jumlah dan Persentase Kuntum Bunga Gugur}

Hasil analisis ragam pada Tabel 4 menunjukkan bahwa pemberian berbagai larutan pengawet yakni akuades, perak nitrat, ekstrak rebusan daun sirih $250 \mathrm{~g} \mathrm{l}^{-1}, 350 \mathrm{~g} \mathrm{l}^{-1}$ dan $450 \mathrm{~g} \mathrm{l}^{-1}$ menunjukkan hasil yang tidak berbeda nyata terhadap jumlah dan persentase kuntum bunga gugur. Kuntum bunga mulai gugur pada $10 \mathrm{HSP}$ dengan perlakuan P0, P1 dan P4. Perlakuan P2 dan P3 mulai mengalami gugur lebih awal pada 8 HSP. Jumlah dan persentase kuntum bunga gugur terus meningkat sampai akhir pengamatan.

Penggunaan perak nitrat dan larutan pengawet rebusan ekstrak daun sirih $250 \mathrm{~g} \mathrm{l}^{-1}$ memberikan hasil persentase kuntum bunga gugur $50 \%$ paling lama yaitu pada 24 HSP. Rata-rata bunga gugur setelah melalui fase layu dan kering terlebih dahulu.

Tabel 4. Jumlah rata-rata dan persentase kuntum bunga gugur anggrek Dendrobium 'Sonia' pada 2- 24 HSP (hari setelah perlakuan)

\begin{tabular}{lccccc}
\hline \multirow{2}{*}{ HSP } & \multicolumn{5}{c}{ Perlakuan } \\
\cline { 2 - 6 } & P0 & P1 & P2 & P3 & P4 \\
\hline 2 & $0.0(0.0 \%)$ & $0.0(0.0 \%)$ & $0.0(0.0 \%)$ & $0.0(0.0 \%)$ & $0.0(0.0 \%)$ \\
4 & $0.0(0.0 \%)$ & $0.0(0.0 \%)$ & $0.0(0.0 \%)$ & $0.0(0.0 \%)$ & $0.0(0.0 \%)$ \\
6 & $0.0(0.0 \%)$ & $0.0(0.0 \%)$ & $0.0(0.0 \%)$ & $0.0(0.0 \%)$ & $0.0(0.0 \%)$ \\
8 & $0.0(0.0 \%)$ & $0.0(0.0 \%)$ & $0.3(2.3 \%)$ & $0.5(5.5 \%)$ & $0.0(0.0 \%)$ \\
10 & $0.8(7.5 \%)$ & $1.3(12.3 \%)$ & $1.0(10.0 \%)$ & $2.0(17.8 \%)$ & $1.0(15.8 \%)$ \\
12 & $1.8(17.5 \%)$ & $1.5(18.8 \%)$ & $2.0(17.8 \%)$ & $2.3(23.5 \%)$ & $1.8(21.0 \%)$ \\
14 & $3.0(29.5 \%)$ & $2.3(22.5 \%)$ & $2.3(20.0 \%)$ & $3.0(29.0 \%)$ & $2.0(23.8 \%)$ \\
16 & $3.8(35.0 \%)$ & $3.0(32.3 \%)$ & $2.3(23.8 \%)$ & $3.3(34.3 \%)$ & $2.8(30.3 \%)$ \\
18 & $4.0(39.3 \%)$ & $3.3(38.5 \%)$ & $3.0(31.0 \%)$ & $3.8(38.5 \%)$ & $3.0(37.0 \%)$ \\
20 & $4.5(42.3 \%)$ & $3.5(40.8 \%)$ & $3.3(35.8 \%)$ & $4.3(42.5 \%)$ & $3.5(44.8 \%)$ \\
22 & $5.3(51.8 \%)$ & $4.3(47.0 \%)$ & $4.5(48.8 \%)$ & $5.0(51.5 \%)$ & $4.0(52.3 \%)$ \\
24 & $5.3(51.8 \%)$ & $4.8(50.8 \%)$ & $4.8(50.8 \%)$ & $5.5(53.5 \%)$ & $4.3(55.5 \%)$ \\
\hline
\end{tabular}

Keterangan: P0: kontrol dengan akuades, P1: Larutan pengawet perak nitrat $0.5 \mathrm{~g} \mathrm{l}^{-1}$, P2: Larutan pengawet daun sirih $250 \mathrm{~g} \mathrm{l}^{-1}, \mathrm{P} 3$ : Larutan pengawet daun sirih $350 \mathrm{~g} \mathrm{l}^{-1}, \mathrm{P} 4$ : Larutan pengawet daun sirih $450 \mathrm{~g}^{-1}$ 
Tabel 5 Jumlah rata-rata dan persentase anggrek Dendrobium 'Sonia' terserang cendawan pada 2-24 HSP (hari setelah perlakuan)

\begin{tabular}{lccccc}
\hline \multirow{2}{*}{ HSP } & \multicolumn{5}{c}{ Perlakuan } \\
\cline { 2 - 6 } & P0 & P1 & P2 & P3 & P4 \\
\hline 2 & $0.0(0.0 \%)$ & $0.0(0.0 \%)$ & $0.0(0.0 \%)$ & $0.0(0.0 \%)$ & $0.0(0.0 \%)$ \\
4 & $0.0(0.0 \%)$ & $0.0(0.0 \%)$ & $0.0(0.0 \%)$ & $0.0(0.0 \%)$ & $0.0(0.0 \%)$ \\
6 & $0.0(0.0 \%)$ & $0.0(0.0 \%)$ & $0.0(0.0 \%)$ & $0.0(0.0 \%)$ & $0.0(0.0 \%)$ \\
8 & $0.0(0.0 \%)$ & $0.0(0.0 \%)$ & $0.0(0.0 \%)$ & $0.0(0.0 \%)$ & $0.0(0.0 \%)$ \\
10 & $0.5(4.8 \%)$ & $0.0(0.0 \%)$ & $0.0(0.0 \%)$ & $1.0(10.5 \%)$ & $0.5(6.3 \%)$ \\
12 & $3.0(28.3 \%)$ & $0.0(0.0 \%)$ & $2.5(28.5 \%)$ & $2.0(20.8 \%)$ & $0.8(9.5 \%)$ \\
14 & $5.3(49.8 \%)$ & $0.0(0.0 \%)$ & $2.8(31.3 \%)$ & $2.3(23.3 \%)$ & $1.3(15.3 \%)$ \\
16 & $5.3(49.8 \%)$ & $0.0(0.0 \%)$ & $2.8(31.3 \%)$ & $2.3(23.3 \%)$ & $1.5(18.5 \%)$ \\
18 & $5.3(49.8 \%)$ & $0.0(0.0 \%)$ & $2.8(31.3 \%)$ & $2.3(23.3 \%)$ & $1.8(21.5 \%)$ \\
20 & $5.3(49.8 \%)$ & $0.0(0.0 \%)$ & $2.8(31.3 \%)$ & $2.3(23.3 \%)$ & $2.0(24.8 \%)$ \\
22 & $4.8(45.0 \%)$ & $0.0(0.0 \%)$ & $2.8(31.3 \%)$ & $1.3(12.8 \%)$ & $2.3(27.8 \%)$ \\
24 & $5.3(49.8 \%)$ & $0.0(0.0 \%)$ & $2.8(31.3 \%)$ & $2.3(23.3 \% 0$ & $2.3(27.8 \%)$ \\
\hline
\end{tabular}

Keterangan: P0: kontrol dengan akuades, P1: Larutan pengawet perak nitrat $0.5 \mathrm{~g} \mathrm{l}^{-1}, \mathrm{P} 2$ : Larutan pengawet daun sirih $250 \mathrm{~g} \mathrm{l}^{-1}, \mathrm{P} 3$ : Larutan pengawet daun sirih $350 \mathrm{~g} \mathrm{l}^{-1}, \mathrm{P} 4$ : Larutan pengawet daun sirih $450 \mathrm{~g}^{-1}$

\section{Jumlah dan Persentase Jumlah Terserang Cendawan}

Hasil pengamatan menunjukkan bahwa perlakuan tidak menunjukkan pengaruh nyata terhadap infeksi cendawan (seperti tertera pada Tabel 5). Perlakuan yang paling awal terinfeksi cendawan dalam jumlah yang cukup tinggi adalah P0. Hal ini disebabkan P0 hanya menggunakan akuades sebagai larutan pengawet dan tidak mengandung bahan germisida. Bahan germisida sangat bermanfaat mencegah adanya mikroorganisme yang dapat masuk dan berkembang biak sehingga umur bunga tidak dapat bertahan lama. Penggunaan perak nitrat memberikan nilai terbaik dengan tidak adanya bunga terserang cendawan sampai akhir pengamatan. Thwala et al. (2013) mengatakan bahwa perak nitrat mengurangi kontaminasi bakteri seperti senyawa anti etilen.

Cendawan yang tumbuh diduga adalah Corticium salmonicolor (jamur upas) berdasarkan ciri-ciri yang dikemukakan oleh Nurcahyawati (2008). Ciri-cirinya yaitu tampak hifa atau miselia cendawan berwarna putih kemerahan. Miselia tampak seperti sarang laba-laba atau sutera mengkilap. Cendawan dapat mnyebabkan kebusukan pada batang, batang mengering, berwarna hitam dan dapat menyebabkan penyumbatan pada ujung tangkai batang sehingga larutan pengawet tidak dapat terserap dengan baik.

\section{Volume Larutan Pengawet Terserap}

Volume larutan pengawet dimasukkan kedalam tabung bunga potong sebanyak $5 \mathrm{ml}$. Volume larutan pada setiap pengamatan mengalami pengurangan dan dihitung sebagai volume larutan yang terserap. Tabung terbuat dari plastik lengkap dengan tutupnya digunakan sebagai wadah larutan pengawet.

Hasil pengamatan berdasarkan Tabel 6 didapatkan bahwa perlakuan memberikan pengaruh nyata terhadap volume larutan yang diserap. Larutan mulai diserap tanaman sejak awal pengamatan pada $2 \mathrm{HSP}$ dengan rata-rata $2.06 \mathrm{ml}$.

Tabel 6. Jumlah rata-rata volume larutan anggrek Dendrobium 'Sonia' terserap pada 2-24 HSP (hari setelah perlakuan)

\begin{tabular}{|c|c|c|c|c|c|c|}
\hline \multirow{3}{*}{ HSP } & \multicolumn{5}{|c|}{ Perlakuan } & \multirow{3}{*}{ Respon } \\
\hline & P0 & $\mathrm{P} 1$ & P2 & P3 & P4 & \\
\hline & \multicolumn{5}{|c|}{-----ml----- } & \\
\hline 2 & $2.9 \mathrm{a}$ & $2.2 b$ & $1.8 \mathrm{c}$ & $2.0 \mathrm{bc}$ & $1.4 \mathrm{~d}$ & $* *$ \\
\hline 4 & $3.6 \mathrm{a}$ & $2.5 b$ & $2.6 \mathrm{~b}$ & $2.8 \mathrm{~b}$ & $1.8 \mathrm{c}$ & $* *$ \\
\hline 6 & $4.0 \mathrm{a}$ & $2.5 \mathrm{c}$ & $3.1 \mathrm{~b}$ & $3.6 \mathrm{a}$ & $2.2 \mathrm{c}$ & $* *$ \\
\hline 8 & $4.1 \mathrm{a}$ & $2.7 \mathrm{~b}$ & $3.7 \mathrm{a}$ & $4.2 \mathrm{a}$ & $2.4 \mathrm{~b}$ & $* *$ \\
\hline 10 & $4.2 \mathrm{a}$ & $2.8 b$ & $3.9 \mathrm{a}$ & $4.4 \mathrm{a}$ & $2.6 \mathrm{~b}$ & $* *$ \\
\hline 12 & $4.4 \mathrm{a}$ & $2.9 \mathrm{~b}$ & $4.2 \mathrm{a}$ & $4.1 \mathrm{a}$ & $2.7 \mathrm{~b}$ & $* *$ \\
\hline 14 & $4.5 \mathrm{a}$ & $3.0 \mathrm{~b}$ & $3.9 \mathrm{a}$ & $4.0 \mathrm{a}$ & $2.9 \mathrm{~b}$ & $* *$ \\
\hline 16 & $6.4 \mathrm{a}$ & $5.8 b$ & $5.7 b$ & $5.9 b c$ & $5.6 \mathrm{~b}$ & $*$ \\
\hline 18 & $6.6 a$ & $5.8 b$ & $5.9 \mathrm{~b}$ & $6.1 \mathrm{~b}$ & $5.8 \mathrm{~b}$ & $* *$ \\
\hline 20 & $6.9 \mathrm{a}$ & $6.0 \mathrm{c}$ & $6.1 b c$ & $6.3 b$ & $6.1 b c$ & $* *$ \\
\hline 22 & $7.3 \mathrm{a}$ & $6.2 b$ & $6.4 \mathrm{~b}$ & $6.4 b$ & $6.2 \mathrm{~b}$ & $* *$ \\
\hline 24 & $7.6 \mathrm{a}$ & $6.2 b$ & $6.5 b$ & $6.6 \mathrm{~b}$ & $6.2 \mathrm{bc}$ & $* *$ \\
\hline
\end{tabular}

Keterangan: P0: kontrol dengan akuades, P1: Larutan pengawet perak nitrat $0.5 \mathrm{~g} \mathrm{l}^{-1}$, P2: Larutan pengawet daun sirih $250 \mathrm{~g} \mathrm{l}^{-1}$, P3: Larutan pengawet daun sirih $350 \mathrm{~g} \mathrm{l}^{-1}$, P4: Larutan pengawet daun sirih $450 \mathrm{~g} \mathrm{l}^{-1}$

${ }^{a}$ Angka yang diikuti huruf yang sama pada kolom yang sama menunjukkan hasil yang tidak berbeda nyata menurut uji DMRT

$*$ = berbeda nyata pada taraf uji $\mathrm{F} 5 \%(\mathrm{P}<0.05)$

** = berbeda sangat nyata pada taraf uji $\mathrm{F} 1 \%$ $(\mathrm{P}<0.01)$ 
Hasil pengukuran sidik ragam pada 16 HSP menunjukkan hasil respon yang memiliki perbedaan yang signifikan. Hal ini disebabkan pada 16 HSP dilakukan penggantian larutan pengawet dalam setiap tabung bunga potong yang digunakan. Hasil volume larutan terserap dihitung kembali dengan menambahkan dengan hasil pengukuran pada hari pengamatan sebelumnya.

Hasil penelitian menunjukkan penggunaan larutan pengawet berupa akuades pada bunga anggrek potong mampu menyerap air lebih banyak yaitu rata-rata sebesar $7.6 \mathrm{ml}$ selama masa pajang. Air akuades sebagai larutan pengawet dapat diserap lebih baik oleh bunga potong dibandingkan dengan perlakuan yang lain karena air yang digunakan merupakan air murni sehingga lebih mudah melewati membran semipermeabel (Kurniawan 2008). Larutan pengawet P4 memiliki kekentalan yang tinggi sehingga peluang terjadinya penyumbatan pada batang lebih besar.

\section{Panjang Batang Dipotong}

Rata-rata panjang batang anggrek sebesar $50 \mathrm{~cm}$ hingga $60 \mathrm{~cm}$. Batang bunga dipotong karena sudah tidak segar lagi, berwarna kuning, mengering, muncul bercak-bercak hitam dan terserang cendawan. Batang yang patah dan terkulai juga dipotong. Hal ini dimaksudkan agar gejala penyakit tidak menyebar ke batang lainnya atau menjalar ke batang atas. Jaringan yang rusak atau busuk dapat meningkatkan gas etilen sehingga menjadi faktor penyebab penurunan mutu bunga (Sunarmani et al., 1998). Pada perlakuan pemotongan 14 HSP menurut uji keragaman, perlakuan tidak berbeda nyata. Hasil rata-rata panjang batang terpotong tertera pada Gambar 1.

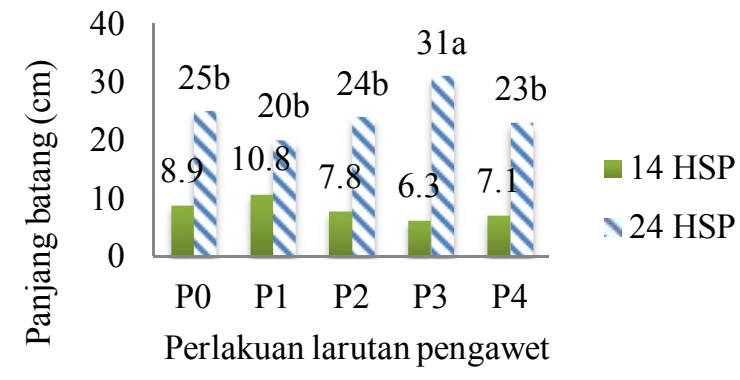

Gambar 1. Panjang rata-rata batang anggrek Dendrobium 'Sonia' dipotong pada 14 HSP dan 24 HSP

Keterangan: P0: kontrol dengan akuades, P1: Larutan pengawet perak nitrat $0.5 \mathrm{~g} \mathrm{l}^{-1}, \mathrm{P} 2$ : Larutan pengawet daun sirih $250 \mathrm{~g} \mathrm{l}^{-1}$, P3: Larutan pengawet daun sirih $350 \mathrm{~g} \mathrm{l}^{-1}$, P4: Larutan pengawet daun sirih $450 \mathrm{~g} \mathrm{l}^{-1}$

${ }^{a}$ Angka yang diikuti huruf yang sama pada kolom yang sama menunjukkan hasil yang tidak berbeda nyata menurut uji DMRT
Batang terpanjang yang dipotong adalah batang dengan perlakuan perak nitrat yaitu sebesar $10.8 \mathrm{~cm}$. Perlakuan dengan larutan daun sirih 450 $\mathrm{g} 1^{-1}$ memberikan hasil nilai batang terpotong yang paling kecil. Pada pemotongan kedua pada 24 HSP, hasilnya menunjukkan perbedaan nyata, dengan batang terpanjang sebesar $31 \mathrm{~cm}$ pada perlakuan daun sirih $350 \mathrm{~g} \mathrm{l}^{-1}$ dan terpendek sebesar $20 \mathrm{~cm}$ pada perlakuan perak nitrat sebesar $20 \mathrm{~cm}$. Hal ini disebabkan karena tidak adanya serangan cendawan dengan perlakuan perak nitrat sehingga batang yang dipotong tidak terlalu besar. Perlakuan daun sirih $350 \mathrm{~g} \mathrm{l}^{-1}$ menunjukkan pemotongan batang paling besar karena juga terdapat batang terkulai dan patah.

\section{Masa Kesegaran Bunga (Vase Life)}

Vase life dihitung dari jumlah kuntum mulai dari awal panen hingga kurang lebih 50\% kuntum bunga mengalami kelayuan (Sunarmani, 2008). Hasil penelitian menunjukkan bahwa penggunaan akuades sebagai larutan pengawet mampu mempertahankan kesegaran bunga sampai 20.5 hari. Penggunaan perak nitrat mempertahankan kesegaran bunga hingga 15 hari. Penggunaan daun sirih dengan komposisi $250 \mathrm{~g} \mathrm{l}^{-1}$ mempertahankan kesegaran bunga hingga 19.5 hari serta penggunaan komposisi daun sirih $350 \mathrm{~g}$ $1^{-1}$ dan $450 \mathrm{~g}^{-1}$ selama 20 hari dan 18.5. Berdasarkan hasil uji ragam menunjukkan perlakuan larutan pengawet tidak berpengaruh nyata dalam memperpanjang masa kesegaran bunga (Gambar 2).

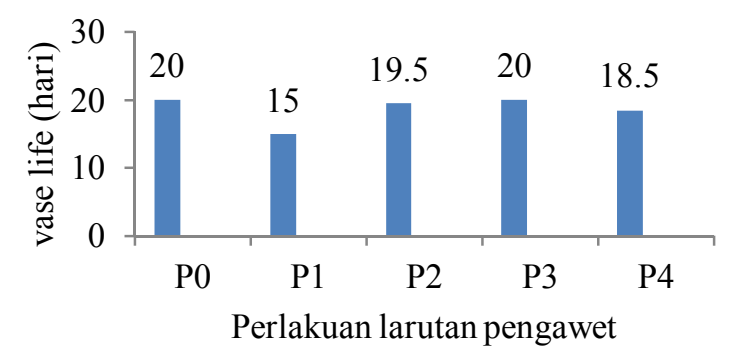

Gambar 2. Masa kesegaran bunga anggrek Dendrobium 'Sonia'

Keterangan: P0: kontrol dengan akuades, P1: Larutan pengawet perak nitrat $0.5 \mathrm{~g} \mathrm{l}^{-1}, \mathrm{P} 2$ : Larutan pengawet daun sirih $250 \mathrm{~g} \mathrm{l}^{-1}$, P3: Larutan pengawet daun sirih $350 \mathrm{~g} \mathrm{l}^{-1}, \mathrm{P} 4$ : Larutan pengawet daun sirih $450 \mathrm{~g} \mathrm{l}^{-1}$

Penggunaan perak nitrat dalam percobaan menunjukkan nilai terkecil diduga karena penggunaannya sebagai larutan pengawet holding bukan pulsing yang lama perendamannya diawal cukup selama 90 menit (BPPP 2007). Bunga yang memiliki vase life yang lebih lama diduga bunga tersebut memiliki kemampuan memproduksi etilen yang rendah dalam proses metabolismenya. 


\section{pH Larutan}

$\mathrm{pH}$ larutan pengawet yang ideal untuk bunga potong sebesar 3 hingga 4.5. Larutan pengawet yang sifatnya asam mengandung banyak ion hidrogen dan bersifat kohesif sehingga lebih mudah terserap dalam pembuluh batang daripada larutan yang netral atau alkalin (Hunter 2000). Larutan yang asam juga dapat menghambat perkembangbiakan cendawan dan bakteri pada larutan pengawet. Asam sitrat digunakan karena mempunyai peranan penting dalam menurunkan $\mathrm{pH}$ di dalam larutan pengawet. Asam sitrat mencegah penyumbatan ikatan vaskular (Thawala et al., 2013). $\mathrm{pH}$ larutan pengawet $\mathrm{P} 1$ dengan campuran perak nitrat sebesar 3.7. Larutan pengawet dengan campuran daun sirih dengan komposisi $250 \mathrm{~g} \mathrm{l}^{-1}, 350 \mathrm{~g} \mathrm{l}^{-1}$ dan $450 \mathrm{~g}^{-1}$ masingmasing menunjukkan $\mathrm{pH}$ sebesar $4.61,4.61$ dan 4.65. Secara keseluruhan larutan pengawet memiliki sifat asam karena nilai $\mathrm{pH}$ menunjukkan nilai dibawah 7 (Gambar 3).

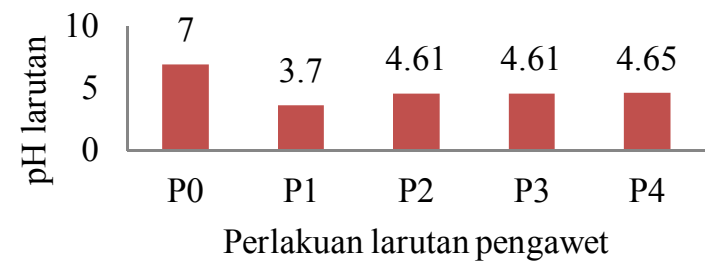

Gambar 3. pH larutan pengawet selama pengamatan

\section{KESIMPULAN}

Hasil penelitian menunjukkan bahwa penggunaan berbagai komposisi larutan pengawet antara akuades, perak nitrat dan ekstrak rebusan daun sirih tidak berbeda nyata dalam memperpanjang umur kesegaran anggrek potong tetapi berbeda terhadap jumlah larutan yang diserap. Anggrek potong mampu menyerap larutan akuades paling tinggi sebesar $7.6 \mathrm{ml}$. Kesegaran bunga anggrek Dendrobium 'Sonia' dapat bertahan hingga 22.5 hari cukup dengan penggunaan akuades. Hal tersebut tidak berbeda signifikan dengan penggunaan perak nitrat yang dapat mempertahankan kesegaran bunga anggrek potong hingga 23.5 hari dan 24 hari dengan penggunaan ekstrak rebusan daun sirih dengan komposisi $250 \mathrm{~g} \mathrm{l}^{-1}+$ asam sitrat $0.15 \mathrm{~g} \mathrm{l}^{-1}+$ gula $100 \mathrm{~g} \mathrm{l}^{-1}$

\section{DAFTAR PUSTAKA}

Amiarsi, D., Yulianingsih. 2004. Formula pengawet untuk bunga anggrek potong.
Prosiding Seminar Nasional Florikultura. Balai Tanaman Hias Indonesia. Bogor.

Badan Penelitian dan Pengembangan Pertanian. 2007. Prospek dan arah pengembangan agribisnis anggrek. http://www.litbang. deptan.go.id/special/publikasi/doc_hortikult ura/anggrek/anggrek-bagian a.pdf. [11 Maret 2014].

Hunter, N.T. 2000. The Art of Floral Design. Delar Thomson Learning.

[IPCS] International Programme on Chemical Safety. 2012. Perak Nitrate. Chemical Safety Information from Intergovernmental Organizations. http://www.inchem.org/. [12 Maret 2014].

Katsum, B.R. 2001. Pengemasan bunga anggrek (Dendrobium sp) dengan sistem atmosfer termodifikasi. [Skripsi]. Institut Pertanian Bogor. Bogor.

Kurniawan, A.A. 2008. Pengaruh komposisi larutan perendam dalam memperpanjang kesegaran anggrek potong dendrobium. [Skripsi]. Universitas Brawijaya. Malang.

Nurcahyawati. 2010. Pengaruh perendaman tangkai bunga dalam $\mathrm{CaCl}_{2}$ terhadap kualitas pascapanen bunga potong anggrek dendrobium "woxinia". [Skripsi]. Institut Pertanian Bogor. Bogor.

Parwata, I.M.O.A., W.S. Rita, R. Yoga. 2009. Isolasi dan uji antiradikal bebas minyak atsiri pada daun sirih (Piper betle Linn.) secara spektroskopi ultra violet-tampak. Jurnal Kimia. 3(1): 7-13.

Sari, R., D. Isadiartuti. 2006. Studi efektifitas sediaan gel antiseptik tangan ekstrak daun sirih (Piper betle Linn.). Majalah Farmasi Indonesia. 17(4): 163-169

Sunarmani, Sabari, Sjaifullah, E. Sitorus. 1998. Pengaruh campuran larutan yang mengandung sukrosa, $\mathrm{AgNO}_{3}$ dan physan20 terhadap kesegaran bunga potong anggrek Dendrobium 'Sonia' Boom. Risalah Seminar Nasional Tanaman Hias. Balai Penelitian Tanaman Hias. Jakarta.

Thwala, M., P.K. Wahome, T.O. Oseni, M.T. Masarirambi. 2013. Effect of floral preservatives on the vase life of orchid (Epidendrum radicans L.) cut flowers. Journal of Horticultural Science \& Ornamental Plants. 5(1): 22-29. doi: 10.5829/idosi.jhsop.2013.5.1.268. 